\title{
The study of reform of college counselors' student management work under the new situation
}

\author{
Jiang-na Cai \\ Security Department , Agricultural University of Hebei, Baoding,China
}

\begin{abstract}
The college counselors' student management work is the university student management organization guidance the students, in accordance with the provisions of the education policy education standards, purposeful, planned, organized the students with all kinds of education, management and service, make the student get development in morality, intelligence, body, beauty, labor and other aspects, the process become builders and successors of socialist modernization. In the new situation, instructor student management work based on the "people-oriented" is a kind of new form. In this form, including the family, school and community environment system, student service system, student evaluation system. They are mutually dependent and coordination exists in each system.
\end{abstract}

Key words: reform, college counselors' student management work, the new situation

\section{Introduction}

In Colleges and universities instructors teaching activity first appeared the concept of "student management, "student management" refers to the students' status management, including registration, examination, upgrade, suspension, attendance, rewards and graduation certificate and so on. But with the development of society, the student management work become more complex, and also became a professional term college counselors often use. The core of this concept is the coordination, management, target. In short, the student management is the general term for the college counselors of students campus life, learning plan, organization, coordination, control the floorboard. It is the university student management organization guidance the students, in accordance with the provisions of the education policy education standards, purposeful, planned, organized the students with all kinds of education, management and service, make the student get development in morality, intelligence, body, beauty, labor and other aspects, the process become builders and successors of socialist modernization.

With the development of society, our country's political, economic and social changes and other factors have a huge development, constant perfection of the socialist market economy, higher education system innovation. Student's management is also given a new historical connotation. It has a deeper meaning. The concept of students' management pay more attention to the growth and success of students education, not just the leadership, the control behavior of the students. In the student management in the process, only by constantly sets up conforms to the time development the new student management idea, expanding and the reform of their management content, the improved method of student management, training objectives can be achieved better talents in universities.

\section{The significance of reform of student management work}

\subsection{The inevitable requirement of a harmonious campus}

construction of harmonious campus is not only in response to the strategic plan of the school construction of Harmonious Society of the Central Committee, is also based on the requirement of the development of school. In the higher education of the elite to mass change process, colleges and Universities Enrollment dramatically increases, increasing the scale of running school, methods are flexible, but the corresponding teaching facilities, teachers condition 
not to be able to timely follow-up, resulting in College

Teachers' current widespread nervousness, per capita resource shortage dilemma, quality and quantity of university education contradictions become difficult to weigh the poles and control, this is clearly and harmonious campus requirements draw further apart.

It has very important significance in the building of harmonious campus. It is not only a response to the construction of the harmonious society, the more is the inevitable choice for the development of our education, to cater to the University's own ascension significance. In the process of popularization of Chinese higher education, it will face many problems and challenges. College enrollment suddenly increased, shortage of school teachers, school running scale increases, the diversified development of educational forms, the school hardware conditions for student management backward makes counselors' work face reform challenges. In the new period of this special, it requires our traditional student management make reform, only in this way, can we realize the construction of the realization of harmonious campus in the new situation .

\subsection{An important guarantee for the implementation of} the Scientific Outlook on Development

Sixteen Party 3 in plenary meeting points out clearly, should "adhere to the people-oriented, establishing comprehensive, coordinated and sustainable development view, promote the economic society and people's overall development". The essence of the scientific development view is the development, the core is people-oriented, the basic requirement is comprehensively coordinated the sustainable, balance is a fundamental method. Now each student has their own characteristics, but also are heading in different direction. Because of the differences between students is more and more big, the traditional mode of college counselors work appeared not adaptability, so that the original pattern is very difficult to achieve a comprehensive, balanced development of students. Therefore, we will Scientific Outlook on Development implementation of the students management reform work, establish the new management system of College counselors.

\subsection{The fundamental requirement for university center task}

Sixteen big reports of the party point out: "education is the foundation of scientific and Technological Development and personnel training, has a leading and decisive role in the modernization construction, must be placed on the priority of the development." Under the new situation, the fundamental task of the reform of student management work of College Instructors in China is to cultivate high-quality talents for the socialist modernization construction. In the process of education in universities undertake social mission and responsibility, to provide comprehensive quality talents for the new situation of social development, implement the strategy of rejuvenating the country goal. University students are the future of our society construction socialism the main force and the main army, undertakes the great mission of building socialism. Therefore, in order to realize the talent quality education, reform will have to implement the student management work of the college counselors.

\section{Analysis of the existing problems in student management work of College Counselors}

\subsection{The existing problems}

\subsubsection{The idea of management can't meet the needs of}

\section{the new situation}

In the new situation, the traditional college counselors' student management work is destined to carry on the reform, however reform is the key influencing factors of college students management concept. At present, the daily work of college counselors is very complicated, and a lot of work becomes to the transaction. In the management work is still in the affairs of the circumstances, the most important is to strengthen the management, the coordinating role of counselors. Transformation from the ideology, improve the role of guidance counselors, rather than a leadership role, to achieve students comprehensive, sustainable development as the core of the work.

In the new historical situation, college counselors should change the thought, renew the concept fundamentally, according to Scientific Outlook on 
Development requirements, implementation of the "people-oriented" in the student in the process, only through the ideological change this, reform can be true for the student management work, so as to realize the comprehensive and sustainable development of students.

\subsubsection{The traditional management mode}

When it comes to work form, the student management of university counselors insist on the form of teach. In the education and management mode, students has been located in the passive, subordinate the position, the process in the management of students, instructors make a mandatory requirement for the students, emphasising on the common realization of student and not special, because the target vector equalization students basic similar, shaping, so as to realize the training goal, students through the passive acceptance of management education, talent target identification. Yet it is this mode of education makes the students reduce the particularity, the lack of individual independence. Therefore, in the process of students' counselors management mainly realizes the goal of students, thus improve the similarity of each person, the difference is reduced, at the same time makes the students' free development limited.

\subsubsection{The students' evaluation system is not perfect}

The traditional education evaluation system has a little prominent defect. The traditional student evaluation system pays attention to the assessment of student achievement, but neglected the evaluation of comprehensive quality of students, so the evaluation result is obviously lose authenticity. Therefore, we should improve the comprehensive evaluation system, paying more attention to student evaluation of performance, fairness, integrity. Therefore, we must devote ourselves to improve these shortcomings. In the new evaluation system, we should highlight the "people-oriented" philosophy, which is a kind of active evaluation system.

\subsection{The cause of the problem}

3.2.1 The accelerate of social change and lag the development of Education

In the current historical situation, the social development of our country is in the key period. At present, China's cultural background includes traditional culture, socialist culture, western culture, so in essence, our country is experiencing the transition from the agricultural society to the modern society, the transformation from a closed and backward society to open the advanced society, the transformation from planned economy to market economy. In such anew historical context, in the transformation process, it must will produce a collision and friction. Thus caused the gap between the development of society and education, so as to the emergence of the backward education development.

\subsubsection{Update the idea of college students' management} slowly

In the development process for a long time, in the process of counselors in student management, thereby strengthening the leading role of counselors very much value the education management, reduce the student's main body status role. The instructor has become subject of student management work process as well as the center, and the students can only as a passive object management. In this process, the instructors mainly emphasize unity, education, management, and not pay attention to the particularity, guide, service. So, in this case, the students' actual needs and abilities have been ignored. The instructor student management project in China in the past activities can be divided into mainly two forms an overview of them, namely the education management model and education management service mode.

4. The reform of college counselors of student management Under the new situation

In the new situation, instructor student management work based on the "people-oriented" is a kind of new form. In this form, including the family, school and community environment system, student service system, student evaluation system. They are mutually dependent and coordination exists in each system.

4.1. The establishment of home school cooperation education environment system

In under the new situation, mutual cooperation in the 
family model, and the school and parents contact system is the main of the establishment. In this way, parents can easily understand the school philosophy and policy. According to the specific national condition, our country at present, most of the parents attach great importance to the academic performance of students. In order to make the student whose grades improve, they can achieve the greatest match. This is the school can effectively use the best human resources. In the process of interaction between parents and schools, can improve the consensus and contact, thus enable the student to obtain the full development, get a better education. The benefit of this model is that more can be found and improve students' flash point. Form in the home school links, we can use the "manual" to contact parents invited to interview and telephone, network information and other parents to the school of communication. In accordance with the requirements of the development of the detailed rules for training students in the home, the control behavior, such as the living behavior, and consciously work habits, health and entertainment and other aspects of the growth and development of price behavior, parents and school self evaluation appraisal unify, promotes the student full, beyond the self development.

\subsection{Improvement of the students' service system}

In under the new situation, with the gradual perfection of market economy and mass higher education is coming, the work of college students management function transformation has been imminent, the realistic foundation of new student management model which is to implement people-oriented. The first point of all, counselor should be to the education and the transfer of management, so as to build up student management service system. Secondly, to further improve the service system positively.

\subsection{The of innovation of students' evaluation system}

In under the new situation, in the management of students in the importance of counselors, student evaluation system is self-evident. However, the defects of the traditional ed ucation evaluation system has been a little prominent, therefore, we must commit to improve these shortcomings. In the new

\section{CONCLUSIONS}

evaluation system, we highlight the "people-oriented" philosophy, which is a kind of active encouragement evaluation system. Counselors help students correct cognition on themselves through evaluation, so as to establish the confidence of the students, then the education evaluation system has little to maximize play. This requires, in the content of the evaluation should also increasingly diversified, not just to score as the main evaluation index. Instructors should pay more attention to the students' innovation spirit, practice ability, psychological quality and family communication ability and so on.

\section{.References}

[1]. Shi qifu, Chen jianhe, "Research on student management model based on the concept of people oriented", LILUN DAOBAO,2013(5)

[2]. Massimo Giannini, "Human capial and income distribution dynamics." $\quad$ Research Economics,2001,N055

[3]. Lor.K.Leslie .'Development and

Education”,EducationJournal,Vol.22.No.2,2004 